Sains Malaysiana 48(11)(2019): 2307-2315

http://dx.doi.org/10.17576/jsm-2019-4811-02

\title{
Urban Expansion Analysis using Landsat Images in Penang, Malaysia
}

(Analisis Pengembangan Bandar menggunakan Imej Landsat di Pulau Pinang, Malaysia)

\author{
Yi Lin TeW, Mou LeONG TAN*, NARIMAH SAMAT \& XIAOYING YANG
}

\section{ABSTRACT}

Urban expansion mapping is important in urban planning, land use and water resources management. The purpose of this study is to evaluate the spatio-temporal trends of urban expansion in Penang using three Landsat satellite images taken in 2004, 2011 and 2018. Maximum Likelihood was used to classify the land uses into urban, agricultural, water, and forest. Comparison of the classified images with time-series Google Earth images and field data collection resulting an accuracy up to 90\%. The results showed that urban have been expanded around 5\% from 2004 to 2018 . Major urban development is mainly found in the eastern part of Penang island. Meanwhile, major development in the Penang mainland can be found in the middle and western regions. Due to the limited development land on the Penang Island, a rapid urban expansion can be found in the south-western part of the Penang mainland that near to the second bridge. In order to maintain the city and community sustainability in Penang, government needs to plan on balanced socioeconomic growth for the near future.

Keywords: Change detection; land use and land cover change; maximum likelihood classifier; Penang; urban growth analysis

\section{ABSTRAK}

Pemetaan keluasan bandar adalah penting dalam perancangan bandar, pengurusan guna tanah dan sumber air. Kajian ini bertujuan untuk menilai corak perubahan ruang-masa kawasan bandar di Pulau Pinang dengan menggunakan tiga imej satelit Landsat yang diambil pada tahun 2004, 2011 dan 2018. Kaedah kebolehjadian maksimum telah diguna pakai untuk mengelaskan jenis guna tanah kepada bandar, pertanian, air dan hutan. Perbandingan antara hasil pengelasan imej dengan imej siri masa Google Earth dan kerja lapangan menunjukkan ketepatan hasil kajian ini mencapai $90 \%$. Keputusan menunjukkan kawasan bandar telah bertambah 5\% dari 2004 hingga 2018. Perkembangan pesat di bahagian Pulau tertumpu di bahagian timur. Manakala perkembangan utama di tanah besar Pulau Pinang boleh didapati di bahagian timur dan selatan. Disebabkan kekurangan tanah pembangunan di bahagian pulau, kawasan di sebelah barat daya tanah besar Pulau Pinang yang berhampiran dengan jambatan kedua telah mengalami perkembangan yang pesat. Oleh itu, kerajaan perlu mengambil tindakan dalam pengimbangan perkembangan sosio-ekonomi selaras dengan perkembangan bandar di negeri Pulau Pinang demi kelestarian bandar dan komuniti pada masa depan.

Kata kunci: Analisis pengembangan bandar; klasifikasi kebolehjadian maksimum; pengesanan perubahan; perubahan guna tanah; Pulau Pinang

\section{INTRODUCTION}

Urbanization is an unavoidable phenomenon around the world. Based on the United Nation, there is about $5 \%$ of urban land globally, but more than $50 \%$ people staying in urban area and the number might reach up to $66 \%$ by the middle of $21^{\text {st }}$ century (Chen et al. 2018; Hu et al. 2018; Tong et al. 2018). Urbanization initiates both economic and social development (Samat et al. 2014). The fast urbanization process in Malaysia was economic factor driven to achieve the status as developed country by year 2020 (Ong et al. 2017). Due to the acceleration of global urbanization trends, the need for urban land has been increasing significantly in recent years (An et al. 2018). Land use and land cover (LULC) change is a dynamic process that directs to urban land expansions (Rimal et al. 2018). Thus, balanced urban land expansion adopted by decision makers is important in achieving sustainable land use and natural resource managements (Mahiny et al. 2012).

In-situ field data survey is a traditional and effective way to assess LULC change. However, this approach has several disadvantages such as time consuming, costly, high manpower, difficulty accessibility to remote regions and highly depend on weather conditions. Remote sensing and Geographic Information Systems (GIS) are therefore very useful in providing historical and current spatially consistent LULC information (Gounaridis et al. 2018). Landsat program, one of the Earth imaging satellite running since 1972, is widely applied in monitoring urban expansion (Chen et al. 2008; Gao et al. 2010).

The determination and evaluation of long-term urban expansion need a spatial comparison of LULC maps 
produced from different satellite images over a same region but collected at different time (An et al. 2018; Geyman et al. 2007; Jia et al. 2018; Zhang et al. 2018). Malaysia is a developing country with rapid urbanization. Malaysia is situated in tropical region, therefore, the sky is always covered with clouds (Mandeep 2008). As cloud cover is one of the main problems in LULC classification, thus, only few studies on urban expansion were reported in Malaysia.

Tan et al. (2010) applied Landsat 5 TM and Landsat 7 ETM+ data to evaluate the LULC changes and land surface temperature extent of Penang from 1999 to 2007. They concluded that remote sensing is an effective tool for evaluating impacts of LULC change towards land surface temperature. Another similar study was done by Masum et al. (2017), who focused on deforestation of Penang. Landsat $5 \mathrm{TM}$ images was used to assess the rate of deforestation on Penang island from 1991 to 2015. However, both studies only considered Penang Island, where Penang mainland was excluded. Penang mainland experienced significant urban development due to the industrialization and the establishment of Northern Corridor Economic Region (NCER) since 2007 where it planned to promote the economy of northern Malaysia to achieve world-class industrial zone by the year 2025 (Kharas et al.2010). In 2010, population in Seberang Perai was 838,999 and estimated to reach 1.1 million in 2020 . The population increment has liberal influence on land resources, to meet the housing and facilities demand, just like what is happening in Penang Island as well.

This study aims to evaluate the spatial and temporal changes in urban land of Penang between 2004 and 2018. Three Landsat images covering the entire Penang state captured by Landsat TM $5(2004,2011)$ and Landsat 8 (2018) were used. These images were pre-processed and classified into four different LULC: water, forest, urban, and agriculture. Maximum likelihood classification was used to classify the images and the results from LULC classification was used to extract the urban expansion with image differencing technique. This study can be used as reference to policy makers and urban planners for future urban planning and management.

\section{MATERIALS AND METHODS}

\section{STUDY AREA}

Penang is located in the northwestern Peninsular Malaysia, with a separation into Penang Island and Penang mainland (Seberang Perai). The entire Penang state is made up with an area of $1,048 \mathrm{~km}^{2}$. Penang is the second smallest state in Malaysia by land mass, but it is the nation's highest population density state $\left(1.684 / \mathrm{km}^{2}\right)$ with population of 1.767 million (Department of Statistics Malaysia 2018).

Department of Statistics Malaysia reported Penang is undergoing rapid economic growth. As a result, Penang has a low unemployment rates and high household income. In 2016, Penang had the second highest GDP per capita (at current prices), ranked after Kuala Lumpur (Ong 2017). In 2018, Penang Chief Minister announced that the future of Penang development will be based on the policies set in Penang 2030 plans, where it is based on four themes: increase livability to enhance quality of life; upgrade the economy to raise household incomes; empower people to strength civic participation; and invest in the built environment to improve societal resilience (Penang State Government 2018).

Like any other states in Malaysia, Penang has tropical rainforest climate bounded on tropical monsoon climate with average annual daily mean temperature around $27.0^{\circ} \mathrm{C}$. The average annual rainfall of Penang is $2670 \mathrm{~mm}$ and relative humidity of $0 \%-50 \%$. The climate system of Penang is largely influenced by the Northeast monsoon season, Southwest monsoon season, surrounding sea and wind systems (Hasan et al. 2012; Mandeep et al. 2008; Tan et al. 2019).

Mountainous are mainly dominated in the middle and northern regions of the Penang Island. The highest elevation point is around $830 \mathrm{~m}$ above sea level at the Western Hill, as shown in Figure 1. On the other hand, low plain area is mainly found in the Penang mainland. The flat terrain at Seberang Perai made it a suitable land for living and agricultural activities.

\section{LANDSAT DATA}

Landsat program is the longest enterprise for Earth imaging that is still running until recent since 1972. Landsat satellite images are widely applied in many applications such as agricultural, forestry, environment, hydrology and geology. One of the main reasons on its popularity is due to its free availability to the public. The images captured by Landsat satellite can be viewed and freely downloaded through the United States Geological Survey (USGS) Earth Explorer website, where they were grouped and organized into scenes for users' convenience in archiving. Each Landsat scene is $185 \mathrm{~km}$ long and $185 \mathrm{~km}$ wide. Up to date, the newest version of Landsat satellite operating is Landsat 8 while Landsat 9 is expected to be launched in December 2020 .

Landsat images are almost ready to use where the image pre-processing was rectified by the producer itself before data distribution. The systematic errors in the sensor can be corrected with modules in remote sensing tools such as FLAASH in ENVI software to conduct atmospheric corrections onto the images.

In this study, the Landsat images were chosen based on the following criteria ( $\mathrm{Su}$ et al. 2017): the total study area in the satellite images must be of cloud free or less than $10 \%$ cloud coverage; and available in long term. Based on the above selection criterion, three Landsat images taken on $16^{\text {th }}$ December 2004, $8^{\text {th }}$ April 2011 and $30^{\text {th }}$ June 2018 were selected. The descriptions and raw images of each dataset used in this study are shown in Table 1 and Figure 2 , respectively. 


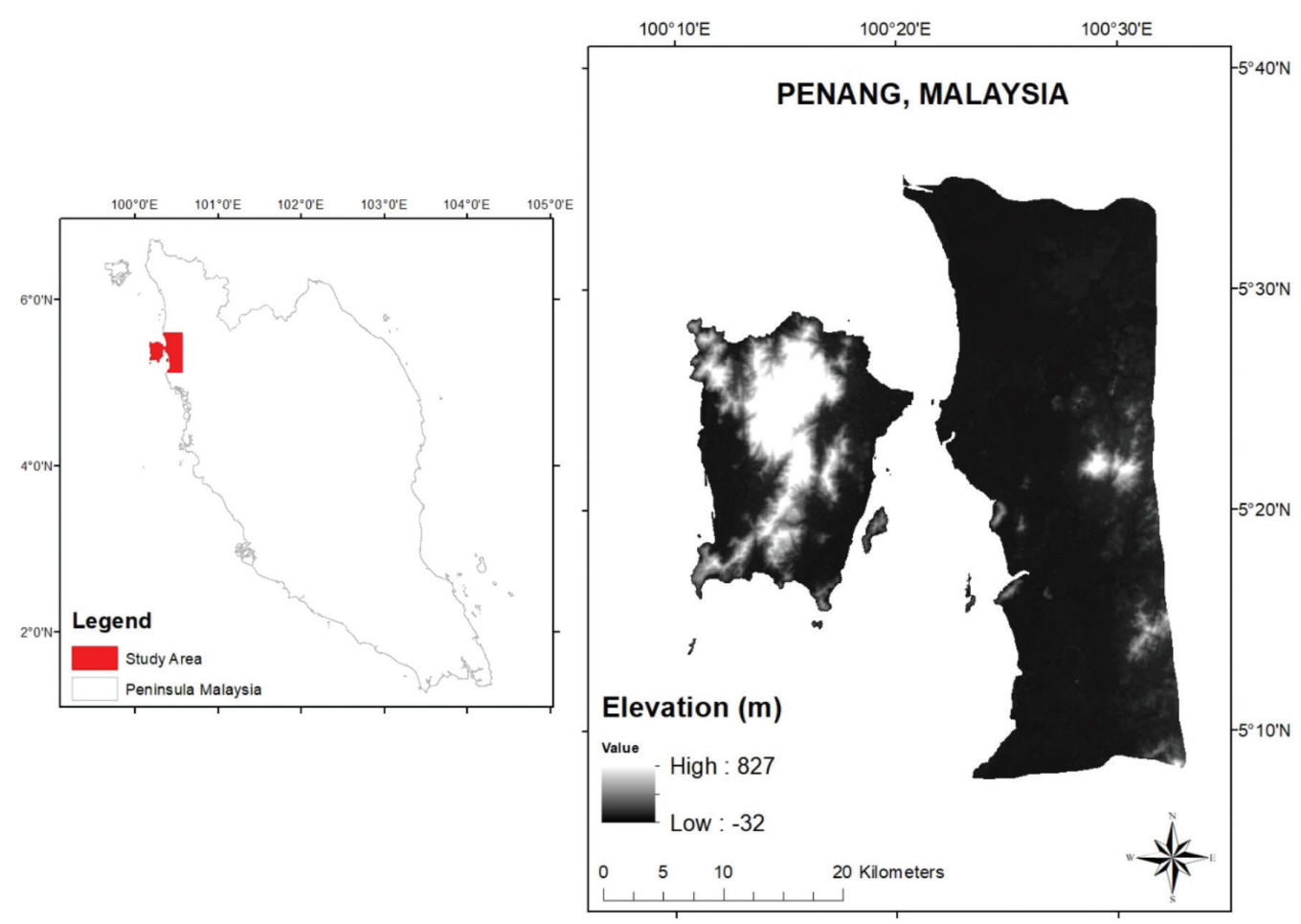

FIGURE 1. Topography of Penang

TABLE 1. Satellite images used in this study

\begin{tabular}{ccccc}
\hline Year & Landsat & Acquisition date & Acquisition time & Sun Azimuth \\
\hline 2004 & 5 & $16^{\text {th }}$ December 2004 & $03: 19: 41$ & 137.23 \\
2011 & 5 & $8^{\text {th }}$ April 2011 & $03: 23: 46$ & 85.89 \\
2018 & 8 & $30^{\text {th }}$ June 2018 & $03: 33: 02$ & 53.66 \\
\hline
\end{tabular}

(a)

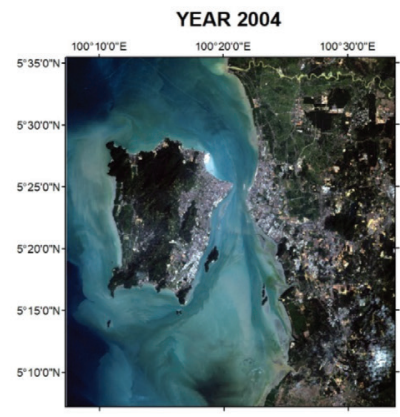

(b)

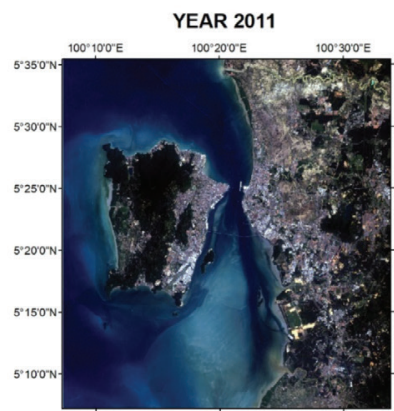

(c)

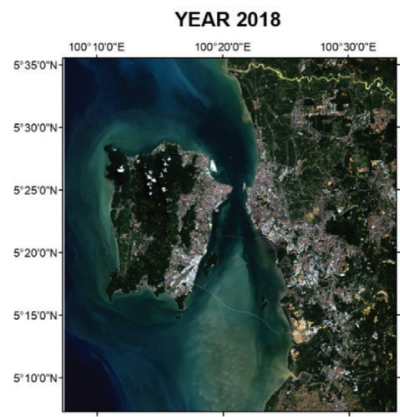

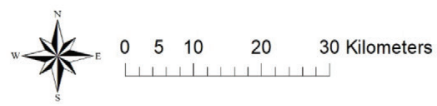

FIGURE 2. Landsat images of Penang captured in (a) 2004; (b) 2011; and (c) 2018 


\section{LANDSAT PRE-PROCESSING}

Radiometric correction is a process of correcting satellite images in terms of correcting errors in digital number. Radiometric correction enables precise conversion of the digital number (DN) of satellite images to radiance unit (L) (Chander et al. 2009), to transfer the image into useful information. The conversion of DN to $\mathrm{L}$ is based on the following equation:

$$
\mathrm{L}_{\lambda}=\left(\frac{L M A X \lambda-L M I N \lambda}{\text { Qcalmax }- \text { Qcalmin }}\right)\left(\mathrm{Q}_{\text {cal }}-\mathrm{Q}_{\text {calmin }}\right)+\mathrm{LMIN}_{\lambda}
$$

where $\mathrm{L}_{\lambda}$, sensor's aperture spectral radiance $\left(\mathrm{Wm}^{-2} \mathrm{sr}^{-1}\right.$ $\left.\mu \mathrm{m}^{-1}\right)$; LMAX $_{\lambda}$ spectral radiance scaled to $\mathrm{Q}_{\text {calmax }}\left(\mathrm{Wm}^{-2} \mathrm{sr}^{-1}\right.$ $\left.\mu \mathrm{m}^{-1}\right) ; \mathrm{LMIN}_{\lambda}$ spectral radiance scaled to $\mathrm{Q}_{\text {calmin }}\left(\mathrm{Wm}^{-2} \mathrm{sr}^{-1}\right.$ $\left.\mu \mathrm{m}^{-1}\right) ; \mathrm{Q}_{\text {calmax }}$ maximum quantized calibrated pixel value $(\mathrm{DN}=255)$ corresponding to $\mathrm{LMAX}_{\lambda} ; \mathrm{Q}_{\text {calmin }}$ minimum quantized calibrated pixel value $(\mathrm{DN}=0)$ corresponding to $\mathrm{LMIN}_{\lambda}$; and $\mathrm{Q}_{\text {cal }}$ quantized calibrated pixel value, commonly known as digital number 'DN'. All the constants were found in the study done by Chander et al. (2009).

The value of radiance obtained earlier was then converted to top of atmosphere (TOA) reflectance by:

$$
\mathrm{P}=\frac{\pi L d^{2}}{E \operatorname{Sun} \pi \cos \theta}
$$

where $\rho$ is the TOA reflectance for band $\lambda$, $\mathrm{d}$, the Earth-Sun distance in astronomical units; ESun the mean solarexoatmospheric irradiance for band $\lambda$; and $\Theta$ is the solar zenith angle in degrees. $\operatorname{ESun}_{\lambda}$ values were obtained to delineate the effect of differing solar zenith angles due to the different time and date of acquisition. TOA reflectance is important as it corrects the uncertainty in the Earth-Sun distance between data acquired at different dates. This reason made TOA reflectance a better measurement than the at-sensor spectral radiance.

The atmospheric effects caused noise in the images when recording reflectance for various types of vegetation. The condition adds when the multi-temporal image is on large area (Xian et al. 2009). Thus, the atmospheric factors in terms of solar irradiance, atmospheric effects caused by absorption, scattering, and noise of the detector in a satellite image must be considered when conducting atmospheric corrections. In this case, the FLAASH module in ENVI software is used for this purpose.

\section{LANDSAT CLASSIFICATION AND ACCURACY ASSESSMENT}

An overview of framework in this study is shown in Figure 3. Image classification was done in order to assign different signatures from the satellite images into different LULC classes. Image classification grouped all pixels in an image into LULC classes to present useful thematic information (Boakye 2008). Training samples were selected by delineating polygons around representative sites for each of the predetermined LULC type by delineating polygons around representative sites, which typically called class region of interest (ROI) selection, works by recording the spectral signature ranges for each LULC classes (Cheruto et al. 2016; Gao et al. 2010; Rozenstein et al. 2011). In this study, Maximum Likelihood classifier is used to classify the images. There are four classes for LULC classification in this study: water, forest, agriculture and urban, as shown in Table 2. For each class, 100 training sites are selected based on the supervised classification decision rule.

The performance of LULC classification results are verified by generating 400 random points and then extract the pixel value to points to extract the LULC information into the points. The random points data was converted into KML files and viewed in Google Earth software to obtain the actual LULC information from the historical views, to generate the overall accuracy of the classification. The measurements of accuracy assessments used for the classification results are the overall accuracy, error matrix and Kappa coefficient.

\section{URBAN CHANGE DETECTION}

Change detection for this study was done by calculating the percentage difference between two consecutive images and the spatial change was made using ArcGIS 10.5 software to detect the changes in the LULC class. The process of

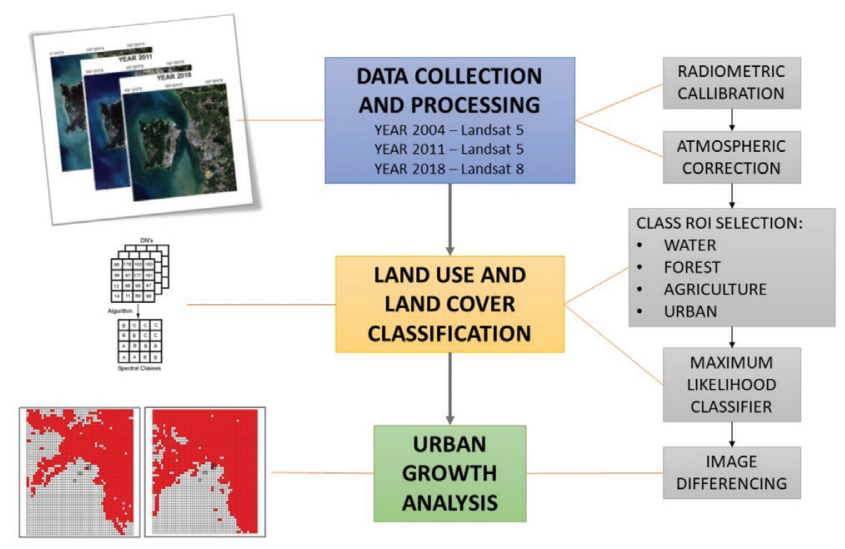

FIGURE 3. Methods workflow 
TABLE 2. Land use and land cover classes in this study

\begin{tabular}{cc}
\hline Land use and land cover class & Description \\
\hline Water & Water dams, rivers, lakes \\
Forest & Deciduous, evergreen, mixed forests \\
Agriculture & Cropland, grassland, orchards, estates \\
Urban & Structure of all types: residential, industrial, commercial and \\
& services, transportation and utilities \\
\hline
\end{tabular}

producing the change detection map is by the pixel-based image differencing method. It works by firstly extracting out the pixels classed in Urban class and then display it.

The changes on the LULC classes between year 2004 and 2011, and 2011 and 2018 was done for this study. Finally, the percentage difference of each LULC class is calculated to compare the difference of the LULC for the year 2004 and 2018.

Percentage difference, $\%=\left(\mathrm{U}_{\mathrm{t} 1}-\mathrm{U}_{\mathrm{t} 0}\right) / \mathrm{U}_{\mathrm{t} 1} \times 100 \%$

where $\mathrm{U}$ is the urban area in $\mathrm{km}^{2}$ between $\mathrm{t}_{1}$ (year 2018) and $t_{0}$ (year 2004). The overall methods workflow is shown in Figure 3.

\section{RESULTS AND DISCUSSION}

\section{LANDSAT ACCURACY ASSESSMENT}

Random sampling method was adopted in this study to collect the samples for validation (Hassan et al. 2017). In this case, 50 samples for each LULC class were generated based on the rule of thumb of Congalton and Green's using Google Earth imagery. This method was applied to the Landsat images taken in 2004 and 2011. Meanwhile, Landsat-8 image taken in 2018 was validated using samples collected from SW Maps mobile GPS application during field trip.

The classified images were validated using the Confusion Matrix module that available in ENVI 5.3 software. Table 3 lists the overall accuracies of the 2004 , 2011 and 2018 classified images are 92.29\%, 88.30\% and $96.60 \%$, respectively. On the other hand, the kappa coefficient values of the three images range from 0.76 to 0.87 , indicating a high accuracy in the classification. This is mainly due to high kappa coefficient value $(0.61-$ 0.80 ) shows a substantial strength of agreement between classified and observed LULC (Landis \& Koch 1977).

\section{URBAN EXPANSION ANALYSIS}

Urban area in Penang expanded from $379.20 \mathrm{~km}^{2}$ in year 2004 to $453.06 \mathrm{~km}^{2}$ in 2018, with an average expansion of $5.28 \mathrm{~km}^{2} /$ year (Table 4 ). Table 4 shows the composition of each land use in each year resulted from the land use classification. Figure 4 shows two main LULC changes situations between 2004 and 2018 in Penang: rapid urban expansion particularly in the middle and southern regions of mainland Penang; and reduction in agricultural area mainly in the area near to the exit of second bridge. The rate of urban expansion in Penang from 2004 to 2018 is about $5.58 \%$. Conversion of oil palm estate to residential or commercial area might be one of the reasons of the reduction in agricultural area in Penang in the last decade.

Figure 4 shows rapid urbanization of Penang in the last few years can be found around Batu Kawan region. Batu Kawan is the connecting point between the mainland and island via the second bridge called the Sultan Abdul Halim Muadzam Shah Bridge. With the launching of Northern

TABLE 3. Accuracies of the classification results

\begin{tabular}{ccc}
\hline Year & Overall accuracy $(\%)$ & Kappa coefficient \\
\hline 2004 & 92.29 & 0.84 \\
2011 & 88.30 & 0.76 \\
2018 & 96.60 & 0.87 \\
\hline
\end{tabular}

TABLE 4. Composition of each land use and land cover class result from image classification

\begin{tabular}{ccccc}
\hline Year & Water & Forest & Agriculture & Urban \\
\hline 2004 & $14.24 \mathrm{~km}^{2}$ & $433.61 \mathrm{~km}^{2}$ & $496.97 \mathrm{~km}^{2}$ & $379.20 \mathrm{~km}^{2}$ \\
& $(1.08 \%)$ & $(32.75 \%)$ & $(37.54 \%)$ & $(28.64 \%)$ \\
2011 & $10.09 \mathrm{~km}^{2}$ & $506.89 \mathrm{~km}^{2}$ & $410.85 \mathrm{~km}^{2}$ & $396.19 \mathrm{~km}^{2}$ \\
& $(0.76 \%)$ & $(31.03 \%)$ & $(38.28 \%)$ & $(29.92 \%)$ \\
2018 & $13.78 \mathrm{~km}^{2}$ & $425.64 \mathrm{~km}^{2}$ & $431.54 \mathrm{~km}^{2}$ & $453.06 \mathrm{~km}^{2}$ \\
& $(1.04 \%)$ & $(32.15 \%)$ & $(32.59 \%)$ & $(34.22 \%)$ \\
\hline
\end{tabular}


(a)

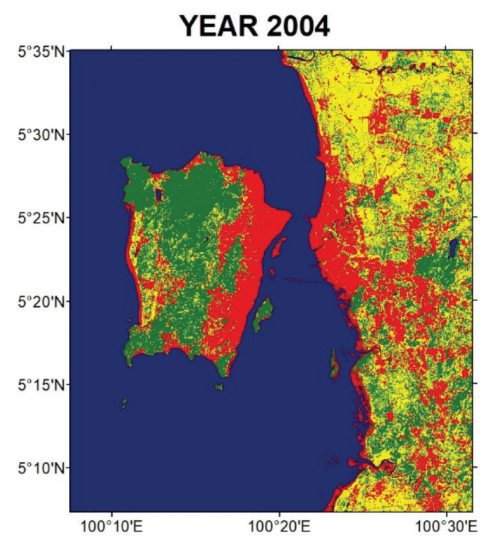

(b)

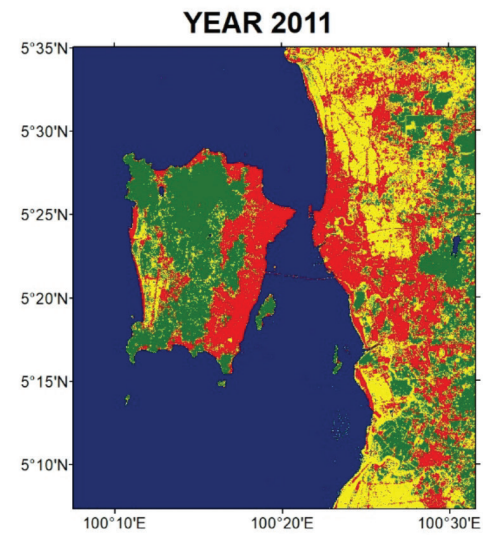

(c)

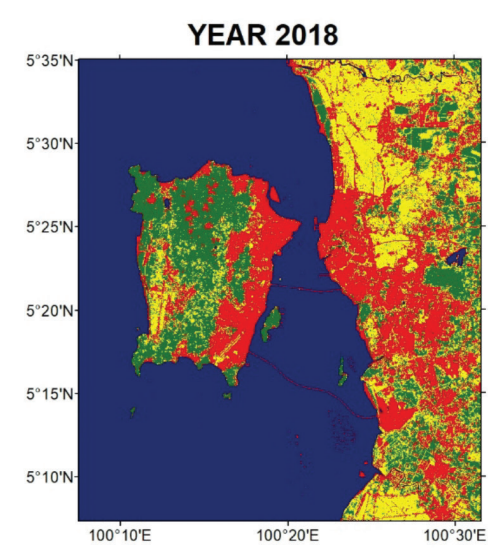

\section{Land Use and Land Cover Class}

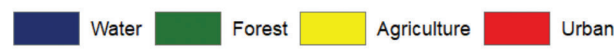

FIGURE 4. Land use and land cover classification mapping: (a) Classification result for year 2004; (b) Classification result for year 2011; (c) Classification result for year 2018

Corridor Economic Region on 2007, about 6,000 acres of oil palm estate previously owned by Batu Kawan Bhd (BKB) was gazetted to Penang Development Cooperation (PDC). Rapid development of Batu Kawan started since 2014, with more than 10,000 units of affordable housing, Batu Kawan Industrial Park (BKIP) and education hub (Khoo 2016).

Besides that, there is also noticeable urban area expansion in the northern part of Penang Island from year 2011 to year 2018 over highly elevated area. This phenomenon was driven by the building of luxury highend residential area at Batu Feringghi bay. The building of such high-end settlements would be a smart growth policy by the local government to promote Penang as a suitable place for retirement with natural scenery views that is close to the city.

However, Yang et al. (2009) suggested that smart growth policies only focused on physical design and provision of public economy values that may not balance with environment sustainability values. Human activities that involved change in land use states are the contributor to natural resources (Ahmad et al. 2016). Excessive exploitation and poor management on natural resources may lead to environmental issues (Asnawi et al. 2016). With big scaled deforestation at hilly areas for buildings, it may cause the area to be more prone towards natural disasters such as landslides and flood.
The map of change detection is shown in Figure 5. By looking at the trend of urbanization in Penang, the rate slowed down in the gap of year 2011 to year 2018 compared to year 2004 to year 2011. This may be due to the certification of Georgetown, the capital city of Penang as the World's Heritage Site since 2008. This certification had boosted the tourism activity in the state and caused the current planning and development focused solely on infrastructure development to achieve the goal to become a sustainable city in 2030. Penang's urban expansion is mainly industrial thrived by the establishment of 169 projects approved in 2014. This certification had followed with foreign investments to set up factories in Penang that makes Penang a town for electronics manufacturing in Malaysia now. The growth of property market in Penang also attracted people to migrate to Penang. Thus, urbanization in Penang is unavoidable for the continuous economy growth of Malaysia.

\section{CONCLUSION}

This study aims to evaluate the urban expansion of Penang from 2004 to 2018 using Landsat images. The results show that Penang undergrown rapid urbanization for the past 14 years. Rapid urbanization was mainly occurred in the middle and southern regions of Penang mainland. 


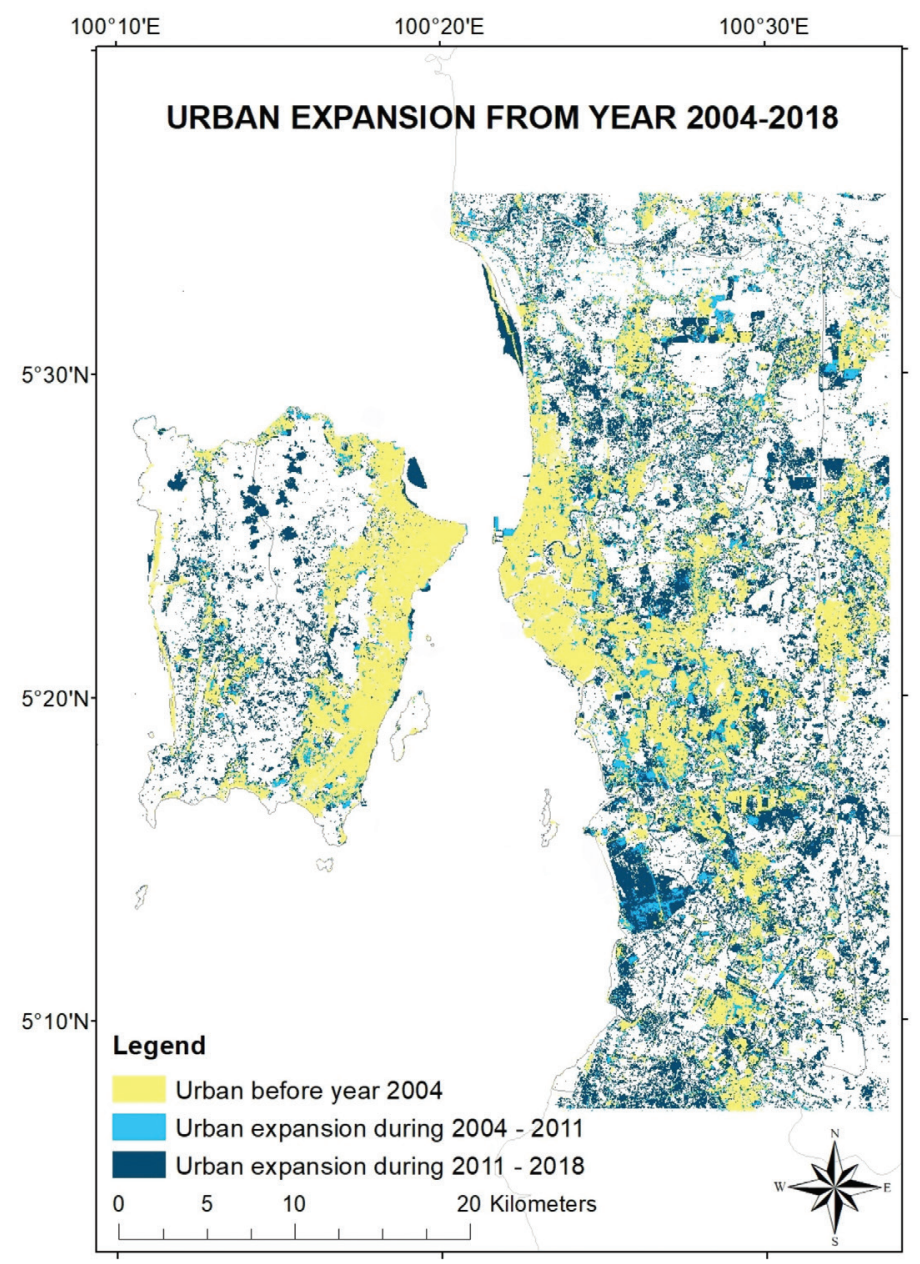

FIGURE 5. Trend of urban expansion in Penang

Meanwhile, conversion of agricultural land to urban area was found in the southern Penang mainland.

Overall, the urban growth in Penang for the past 14 years was aimed to fulfill the people's need for economic growth in terms of urban building developments. In order to achieve the goal to become a sustainable city by 2030, an environment that connects people via efficient public infrastructure, to homes, amenities, centers of employment and trade shall be created.

Geographical Information System (GIS) and remote sensing techniques are believed to be powerful tools for urban expansion studies. As proven in this study, the application of Landsat 5 and 8 data in land use mapping has high level of accuracy. However, there are still several considerations in this study, such as the limitation of Landsat data. The spatial resolution of Landsat data is $30 \mathrm{~m}$ and Landsat 5 only records data in 7 bands, there is tendency that tradeoffs between the spatial and spectral resolution of the data to the reality. Besides, cloud cover is another issue of using Landsat data where the parts with thick cloud cover could not be used for data analyzation. In this case, data of year 2004, 2011 and 2018 were used because these are the established dataset with least cloud cover for Penang. In order to enhance the results for image classification with Landsat data, multisensory data fusion method shall be included in the future studies.

\section{ACKNOWLEDGEMENTS}

This research was funded by the Ministry of Education, Malaysia under the NEWTON-NERC grant (IMpacts of PRecipitation from Extreme StormS - Malaysia (IMPRESSMALAYSIA), 203.PHUMANITI.6780001) and Fundamental Research Grant Scheme (203.PHUMANITI.6711695), and the Belt and Road Special Foundation of the State Key Laboratory of Hydrology - Water Resources and Hydraulic Engineering at Nanjing Hydraulic Research Institute, China (2018nkzd01). The authors also thank for the opportunity to work at Fudan University for two months under the Fudan Scholar Program. The authors would like to acknowledge the contributions of the editor for the editing assistance as well as to thank the reviewers for their valuable comments and suggestions.

\section{REFERENCES}

Ahmad, M.S., Fahmi, M.R., Rahim, M.A. \& Ibrahim, N. 2016. Kesan gabungan aktiviti guna tanah dan perubahan musim 
terhadap kualiti sumber air: Kajian kes di terusan Utara, Kedah. Sains Malaysiana 45(12): 1857-1867.

An, Y., Tsou, J.Y., Wong, K., Zhang, Y., Liu, D. \& Li, Y. 2018. Detecting land use changes in a rapidly developing city during 1990-2017 using satellite imagery: A case study in Hangzhou urban area, China. Sustainability 10(9): 3303.

Asnawi, N.H. \& Lam, K.C. 2016. Analisis perubahan guna tanah dan litupan bumi di Gombak, Selangor menggunakan data penderiaan Jauh. Sains Malaysiana 45(12): 1869-1877.

Boakye, E., Odai, S.N., Adjei, K.A. \& Amor, F.O. 2008. Landsat images for assessment of the impact of land use and land cover changes on the Barekese Catchment in Ghana. European Journal of Scientific Research 21(4): 617-626.

Chander, G., Markham, B.L. \& Helder, D.L. 2009. Summary of current radiometric calibration coefficints for Landsat MSS, TM, EM+, and EO-1 ALI sensors. Remote Sensing of Environment 113: 893-903.

Chen, L., Ren, C., Zhang, B., Wang, Z. \& Liu, M. 2018. Quantifying urban land sprawl and its driving forces in Northeast China from 1990 to 2015. Sustainability 10(1): 188.

Chen, S. \& Rao, P. 2008. Land degradation monitoring using multi-temporal Landsat TM/ETM data in a transition zone between grassland and cropland of northeast China. International Journal of Remote Sensing 29(7): 2055-2073.

Cheruto, M.C., Kauti, M.K., Klsangau, P.D. \& Katuki, P. 2016. Assessment of land use and land cover change using GIS and remote sensing techniques: A case study of Makueni County, Kenya. Journal of Remote Sensing \& GIS 5(4): 175.

Gao, J. \& Liu, Y. 2010. Determination of land degradation causes in Tongyu County, Northeast China via land cover change detection. International Journal of Applied Earth Observation and Geoinformation 12: 9-16.

Geyman, A. \& Baz, I. 2007. Monitoring urban growth and detecting land-cover changes on the Istanbul metropolitan area. Environment Monitoring Assessment 136(3): 449-459.

Gounaridis, D., Symeonakis, E., Chorianopoulos, I. \& Koukoulas, S. 2018. Incorporating density in spatiotemporal land use/cover change patterns: The case of Attica, Greece. Remote Sensing 10(7): 1034.

Hasan, H.B., Radi, N.F.B.A. \& Kassim, S.B. 2012. Modeling of extreme temperature using Generalized Extreme Value (GEV) distribution: A case study of Penang. Proceedings of the World Congress on Engineering, July 4 - 6, 2012, London, U.K. Volume I.

Hassan, M.M. \& Southworth, J. 2017. Analyzing land cover change and urban growth trajectories of the Mega-Urban Region of Dhaka using remotely sensed data and an ensemble classifier. Sustainability 10(10): 24.

Hu, Y., Kong, X., Zheng, Ji., Sun, J., Wang, L. \& Min, M. 2018. Urban expansion and farmland loss in Beijing during 19802015. Sustainability 10(11): 3927.

Jia, Z., Ma, B., Zhang, J. \& Zeng, W. 2018. Simulating spatialtemporal changes of land-use based on ecological redline restrictions and landscape driving factors: A case study in Beijing. Sustainability 10(4): 1299.

Kharas, H. 2010. The Unprecedented Expansion of the Global Middle Class. Washington: Global Economy \& Development at Brookings.

Khoo, N. 2016. Batu Kawan's future potential. EdgeProp Smarter property seach. https://www.edgeprop.my/ content $/ 1000715 /$ batu-kawan $\%$ E2\% $80 \% 99$ s-futurepotential\#
Landis, J.R. \& Koch, G.G. 1977. A One-way components of variance model for categorial data. Biometrics 33(4): 671-679.

Mahiny, A.S. \& Keith, C. 2012. Guiding SLEUTH landuse/land-cover change modeling using multicriteria evaluation: Towards dynamic sustainable land-use planning. Environment and Planning B Planning and Design 39: 21. https://doi.org/10.1068/b37092.

Mandeep, J.S. \& Hassan, S.I.S. 2008. Cloud attenuation for satellite applications over equatorial climate. IEEE Antennas and Wireless Propagation Letters 7: 152-154.

Masum, K.M., Mansor, A., Sah, S.A.M. \& Lim, H.S. 2017. Effect of differential forest management on land-use change (LUC) in a tropical hill forest of Malaysia. Journal of Environmental Management 200: 468-474.

Ong, K.M. \& Tan, B.T.N. 2017. Penang's Economy is Healthy and Strong, with Incomes Rising and Inequality Decreasing. Penang Institute Issues November 2017.

Penang State Government. 2018. Penang 2030: A FamilyFocused Green and Smart State to Inspire the Nation. https://www.penang.gov.my/kenyataan-akhbar/360297penang-2030-a-family-focused-green-and-smart-state-toinspire-the-nation.

Rimal, B., Zhang, L., Stork, N., Sloan, S. \& Rijal, S. 2018. Urban expansion occured at the expense of agricultural lands in the Tarai Region of Nepal from 1989 to 2016. Sustainability 10: 1341

Rozenstein, O. \& Karnieli, A. 2011. Comparison of methods for land-use classification incorporating remote sensing and GIS inputs. Applied Geography 31(2): 533-544.

Samat, N., Ghazali, S., Hasni, R. \& Elhadary, Y. 2014. Urban expansion and its impact on local communities: A case study of Seberang Perai, Penang, Malaysia. Social Science \& Humanities 2(22): 349-367.

Su, S., Sun, Y., Lei, C., Weng, M. \& Cai, Z. 2017. Reorienting paradoxial land use policies towards coherence: A selfadaptive ensemble learning geo-simulation of tea expansion under different scenarios in subtropical China. Land Use Policy 67(11): 0624-8377.

Tan, K.C., Lim, H.S., MatJafri, M.Z. \& Abdullah, K. 2010. Landsat data to evaluate urban expansionand determine land use/land cover changes in Penang Island, Malaysia. Environmental Earth Sciences 60(7): 1509-1521.

Tan, M.L., Samat, N., Chan, N.W., Lee, A.J. \& Li, C. 2019. Analysis of precipitation and temperature extremes over the Muda River Basin, Malaysia. Water 11(2): 283.

Tong, S., Dong, Z., Zhang, J., Bao, Y., Guna, A. \& Bao, Y. 2018. Spatiotemporal variations of land use/cover changes in Inner Mongolia (China) during 1980-2015. Sustainability 10: 4730

Yang, F. 2009. If 'Smart' is 'Sustainable'? An analysis of Smart Growth Policies and its successful practices. Graduate Theses and Dissertations. Iowa: Iowa State University (Unpublished).

Zhang, Y., Wang, P., Wang, T., Cai, C., Li, Z. \& Teng, M. 2018. scenarios simulation of spatio-temporal land use changes for exploring sustainable management strategies. Sustainability 10: 1013 .

Yi Lin Tew, Mou Leong Tan* \& Narimah Samat Geography Section School of Humanities 
Universiti Sains Malaysia

11800 Pulau Pinang

Malaysia

XiaoYing Yang

Department of Environmental Science and Engineering

Fudan University

No. 220 Handan Rd

Shanghai 200433

China
*Corresponding author; email: mouleong@usm.my

Received: 31 March 2019

Accepted: 15 August 2019 